\title{
An Examination of the Merchandise Imports Demand Function for Egypt
}

\author{
Mohamed Abbas Ibrahim ${ }^{1}$ \\ ${ }^{1}$ Department of Economics, Faculty of Commerce, Aswan University, PO Box 81524, Aswan, Egypt \\ Correspondence: Mohamed Abbas Ibrahim, Department of Economics, Faculty of Commerce, Aswan University, PO \\ Box 81524, Aswan, Egypt.
}

Received: November 8, 2016

Accepted: January 7, $2017 \quad$ Available online: January 14, 2017

doi:10.11114/aef.v4i2.1969

URL: http://dx.doi.org/10.11114/aef.v4i2.1969

\begin{abstract}
Merchandise imports in Egypt is growing steadily and very rapidly, at an average growth rate of 10.64 percent/year during 1970-2014. So, this study is very important to know the merchandise imports determinants in Egyptian economy. This study empirically estimates the critical parameters of merchandise import demand determinants for Egypt by using Ordinary Least Squares (OLS) approach and Error Correction model during the period (1970-2014).

The empirical results confirm that, in both long run and short run, there is positive and significant relationship between the demand for merchandise imports and real gross domestic product, but there is a negative and significant relationship between the demand of merchandise imports and real effective exchange rate. On the other hand, in the long run, there are positive and significant relationships between the demand for merchandise imports and both of inflation and international reserves but insignificant relationships in the short run.
\end{abstract}

JEL Classification: C22, F62, P33

Keywords: international trade, merchandise import demand, error correction model, Egypt

\section{Introduction}

In recent years, the trade deficit has been an intensive subject of interest in Egypt. So, questions were raised about the factors that can affect the trade deficit in Egyptian Economy Managing and decreasing imports, specially merchandise imports were one of the solutions that presented to affect trade deficit in Egypt. Imports play an important role in developing economies. However, through it countries can safe goods and services that can't be produced domestically. Many empirical studies estimated the import demand functions for advanced countries and developing countries to determine economic variables that affect the behavior of merchandise import demand over time. So, this study is very important to know the merchandise import determinants in Egyptian economy, which can be used in formulating economic policy that help controlling trade deficit in Egypt.

The paper is structured as follows: Introduction in Section 1. Section 2 presents the theoretical background on which the models are based and gives an empirical review of the literature. Section 3 provides some stylized facts about Egyptian economy and the behavior of merchandise import demand determinants in Egypt. Section 4 discusses the data, evaluates the specifications of the economic models and describes the econometric methodology that will be adopted. Section 5 reports on the empirical results and Section 6 summarizes the concluding remarks.

\section{Recent Empirical Studies}

To the best of the researcher's knowledge, there are no studies for Egypt that investigated the merchandise import determinants but few studies estimated the import demand function. However, Ibrahim (2015) investigated the critical parameters of merchandise import demand determinants for Saudi Arabia by using Ordinary Least Squares (OLS) approach and Error Correction model during the period (1975-2011). The empirical results obtained show that, in both long run and short run, there are positive and significant relationships between the demand for merchandise import and real gross domestic product, gross capital formation expenditure, private consumption expenditure, government consumption expenditure and the relative price of imports to domestic price. On the other hand, there are positive but insignificant relationship between the demand for merchandise import and international reserves either in the long run or the short run.

Doroodian et al. (1994) investigated the import demand determinants for Saudi Arabia based on annual data for the 
period 1963-90. The results suggested a number of aspects that characterize the Saudi Arabia import demand function. First, econometric evidence illustrated that, for standard specifications of the import demand function, the log-linear formulation was more appropriate than the linear one. Secondly, empirical result showed that, in the case of Saudi Arabia, the relative price formulation of the traditional import demand function is inappropriate for estimating elasticities of import demand. Aldakhil and Al-Yousef (2002) estimated Saudi Arabia's aggregate demand for imports during the period 1968-98 by using cointegration analysis and error correction approach. They found that, domestic price, import price, and income are important in determining the import demand. Arize and Malindretos (2012) carry out an empirical investigation of the short-run and long-run impact of domestic income, relative import prices, and foreign reserves on real imports for selected Asian economies. They employ a number of econometric methods-the Johansen and Harris-Inder cointegration techniques, fully modified ordinary least squares (OLS), dynamic OLS, and the ARDL model - and find that foreign exchange reserves are an important determinant of imports. In line with theory, the effect of foreign exchange reserves is positive. Thus, policies aimed at increasing foreign exchange reserves will encourage imports. The estimates also show that real income is a significant variable in explaining the demand for imports and that income elasticity is highly elastic for India, the Republic of Korea, and Thailand, but inelastic for Japan and Singapore. A high degree of income elasticity implies that higher income growth will lead to a greater trade imbalance. Finally, the results indicate that rising relative prices significantly discourage imports. Aljebrin and Ibrahim (2012) estimated the critical parameters of import demand determinants for GCC countries (Bahrain, United Arab Emirates, Kuwait, Oman Qatar and Saudi Arabia) by using annual time series-cross section data (1994-2008) and by applying panel Seemingly Unrelated Regression (SUR) model. The empirical results showed that, in both long run and short run, there are positive and significant relationships between the demand for imports and real income, private consumption, international reserves and gross capital formation. On the other hand, there are negative and significant relationships between the demand for imports and the relative price of imports to domestic price and government consumption in the long run, but negative and insignificant relationships in the short run.

Foreign exchange reserves are also seen as an important determinant of imports because they directly determine the international liquidity available to a country for purchasing imports. A country with high foreign exchange reserves also has room to pursue less restrictive trade policies. Rashid and Razzaq (2010) model the import demand function for Pakistan and argue that there is a binding foreign exchange constraint on imports. Apart from relative prices and income, they add exchange rate reserves to their model to study the impact of foreign exchange availability. The results suggest that there is a long-run relationship between foreign exchange reserves and imports, implying the presence of a foreign exchange availability constraint on imports. The coefficients of price and income elasticity are higher than the previous estimates, indicating that, after accounting for the effect of the foreign exchange constraint, imports become more sensitive to changes in income and relative prices.

Metwally (2004) investigated the impact of the fluctuations in oil exports on Gulf Cooperation Council (GCC) spending on imports and estimated the long-run relationship between the imports of each GCC member and the macroeconomic components of final expenditure (exports, government consumption, investment and private consumption) using the Johansen multivariate cointegration analysis. He confirmed that the demand for imports was highly elastic with respect to GDP in all GCC countries studied (with the exception of Oman) during the last three decades.

On the other hand, many authors investigated the import demand function in developing countries. For Turkey, Erlat and Erlat (1991) analyzed Turkish export and import performance by using annual data for the period 1967-87. Export supply, export demand and import demand functions were investigated by ordinary least squares (OLS) first, and then three equations were estimated as a set of seemingly unrelated regressions (SURs). The total volume of imports was regressed on domestic real income, real international reserves, price of imports divided by domestic prices and one period lagged value of the dependent variable. Two dummies were introduced for the years 1978 and 1979 to explain structural shifts. International reserves were found to be the most important variable in explaining import demand. Relative prices, however, had no significant explanatory power on import demand. Kotan and Saygili (1999) investigated an import demand function for Turkey. They incorporated two different model specifications to investigate the import demand function for Turkey. The estimation performance of the two models was compared and contrasted for the period 1987: Q1-1999:Q1 by using quarterly data. The significance of variables that affected import demand was individually and jointly investigated. Also, the short run elasticities of the two models were compared. The first model estimated imports using the Engle-Granger approach. The results confirmed that in the long run, income level, inflation rate, nominal depreciation rate and international reserves insignificantly affect imports. The second approach models import demand using the Bernanke-Sims structural vector autoregressive (VAR) method. The results showed that anticipated changes in the real depreciation rate and unanticipated changes in the income growth and real depreciation rate have significant effects on import demand growth.

Mohammed and Tang (2000), used the Johansen and Juselius cointegration technique and investigated the determinants of aggregate import demand for Malaysia, over the period 1970-1998. The results showed that while all expenditure 
components had an inelastic effect on import demand in the long run, investment expenditure had the highest correlation with imports followed by final consumption expenditure. Expenditure on exports was found to have the smallest correlation with imports. They also found a negative and inelastic relationship between relative prices and import demand. All results confirmed the statistically significant relationship at the 1 per cent level.

Alias and Tang (2000) investigated the long-run relationship between Malaysian aggregate imports and the components of final demand expenditure and relative prices using the Johansen multivariate cointegration analysis. An error correction model is suggested to model the short-run response of imports to its determinants. Annual data for the period 1970 to 1998 are used. The long-run relationship between aggregate imports and the macroeconomic components of final demand expenditure namely public and private consumption expenditure, investment expenditure and exports, is investigated because the different components of final demand might have different import contents. The results of the analysis showed that the components of final demand expenditure and relative prices are all important in determining aggregate demand for imports in both the long-run and the short-run.

Dutta et al. (2006) tested the behavior of Indian aggregate imports during the period 1971-1995. In their empirical analysis of the aggregate import demand function for India, cointegration and error correction modeling approaches were adopted. In the aggregate import demand function for India, import volume is found to be cointegrated with relative import price and real GDP. The aggregate import volume is found to be price-inelastic. The value of income elasticity of demand for imports lagged two years is greater than unity, implying that the demand for imports increases more than proportionately to the increase in real gross domestic product.

Sinha's (2001) study showed that the price and income demand elasticities are inelastic in Japan, India, the Philippines, Thailand and Sri Lanka. Bahmani-Oskooee (1998) identifies the foreign exchange rate as an important determinant of import demand for six developing countries (Pakistan, Greece, the Philippines, Singapore, the Republic of Korea, and South Africa). He employs the Marshall-Lerner condition, which implies that, for devaluation to have a positive effect on imports, the sum of the elasticities of the import and export demand functions should be greater than 1 . Thus, there are two effects attached to devaluation: it will lead to a fall in imports and a rise in exports because exports are now relatively cheap. If the Marshall-Lerner condition is satisfied, then the positive export effect will be greater than the negative import effect. The author's analysis indicates that this condition is satisfied for almost all the countries in the sample, implying that devaluation has positive effects and is, arguably, a good instrument for improving the trade balance.

For, developed countries, Carone (1996) investigated the American demand for imports using quarterly data 1970 to 1992 based on the cointegration and error correction approaches. They confirmed the statistically significant long-run relationship between the import demand function and real income and relative prices. Stirbock (2006) introduced a single error-correction analysis of German, euro-area and non-euro-area import demand for the 1980-2004 period and found that, German import demand is driven largely by domestic and foreign demand and less by changes in relative prices.

\section{Stylized Facts about Egyptian Economy and the Behavior of Merchandise Import Demand in Egypt}

Egypt is classified as a lower-middle income country with a real per capita Gross Domestic Product (constant 2005 US\$) in 2014 of $\$ 1467$. It is one of Middle East and North Africa (MENA) countries that boost a population of 89.6 million, as of 2014. However, over the past decade, Egypt achieved major economic progress. Its real GDP grew at about $6.3 \%$ during 1970-2014; foreign direct investment inflows amounted by 4.78 billion dollars, which represents 1.67\% of GDP in 2014 (http://data.worldbank.org/indicator/). This performance was accompanied by increased trade openness, export promotion policies.

Imports play an important role in the economic growth and development of many countries. However, through it countries can safe goods and services that can't be produced domestically. Many empirical studies estimated the import demand functions for advanced countries and developing countries to determine economic variables that affect the behavior of import demand over time. In this respect, measuring income and price elasticities of import demand has received much attention because of the implications on trade policy and balance of payments issues.

As shown in table 1, total trade has increased from 1.88 billion dollars to 134 billion dollars during the period 1970-2014, with average growth rate $10.18 \%$. At the same period, trade/GDP ratio increased from $24.48 \%$ to $46.77 \%$ at the same period, so this ratio has been doubled during the period (World Bank, World Bank Development Indicator, http://data.worldbank.org/indicator/) 
Table 1. Some key trade indicators of Egypt (1970-2014)

\begin{tabular}{lllll}
\hline & \multicolumn{2}{l}{ Value (billion dollar) } & \multicolumn{2}{l}{ \% of GDP* } \\
\cline { 2 - 5 } & 1970 & 2014 & 1970 & 2014 \\
\hline Merchandise Exports & 0.76 & 27.1 & 9.93 & 9.46 \\
Services Exports & 0.34 & 21.9 & 4.43 & 7.64 \\
Total Exports & 1.1 & 49 & 14.32 & 17.1 \\
Merchandise Imports & 0.79 & 67.5 & 10.29 & 23.56 \\
Services Imports & 0.65 & 17.5 & 8.46 & 6.11 \\
Total Imports & 1.44 & 85 & 18.75 & 29.66 \\
Total Trade & 1.88 & 134 & 24.48 & 46.77 \\
\hline
\end{tabular}

Source: http://data.worldbank.org/indicator/.

* calculated by the author.

Table 2 illustrates that trade account balance suffering from increasingly deficit from 0.34 billion dollars to 36 billion dollars during the period 1970-2014, with annual average growth rate amounted by 11.18 percent. Although the merchandise account balance deficit increased dramatically with average growth rate 17.49 percent during the period 1970-2014. On the other hand, services account balance during the same period changed from deficit to surplus during the period 1970-2014, with average growth rate 15.02 percent. The higher average growth rates of the trade and the merchandise account balance deficits increase the necessity of find solutions for controlling this problem.

Table 2. Trade account (1975-2014)

\begin{tabular}{lllllll}
\hline & \multicolumn{2}{l}{ Value (billion dollar) } & $\begin{array}{l}\text { Average } \\
\text { Growth rate(\%) }\end{array}$ & Annual GDP* & \\
\cline { 2 - 6 } & 1970 & 2014 & $1970-2014$ & 1970 & 2014 \\
\hline Merchandise Exports & 0.76 & 27.1 & 8.46 & & \\
Merchandise Imports & 0.79 & 67.5 & 10.64 & & \\
Merchandise Account Balance & -0.03 & -40.4 & 17.49 & 0.39 & 15.05 \\
Services Exports & 0.34 & 21.9 & 9.93 & & \\
Services Imports & 0.65 & 17.5 & 7.77 & & \\
Services Account Balance & -0.31 & 4.4 & 15.02 & 4.04 & 1.54 \\
Trade Account Balance & -0.34 & -36 & 11.18 & 4.43 & 12.57 \\
\hline
\end{tabular}

Source: http://data.worldbank.org/indicator/.

* calculated by the author.

In analyzing the Egyptian merchandise import performance, the structure of merchandise import has to be analyzed. Table 3 presents the structure of merchandise import in 1970 and 2014; the average growth rates of merchandise imports components during the period and its shares of total merchandise imports. We can observe that manufactures, ores and metals and Agricultural raw materials achieved the highest yearly average growth rate during the period 1975-2014. Food imports achieved average growth rate during the same period amounted by $4.99 \%$ but it has a highest share of total merchandise imports reached to $21.1 \%$. 
Table 3 . The structure of merchandise imports and its yearly average growth rates 1970-2014

\begin{tabular}{lllllll}
\hline \multirow{2}{*}{ Merchandise Imports } & \multicolumn{3}{l}{ Value (billion dollar) } & $\begin{array}{l}\text { Yearly } \\
\text { Growth Rate* (\%) }\end{array}$ & $\begin{array}{l}\text { Average of } \\
\text { Imports* }\end{array}$ \\
\cline { 2 - 7 } & 1970 & 2014 & $1970-2014$ & 1970 & 2014 \\
\hline Manufactures & 0.035 & 2.97 & 10.62 & 4.43 & 4.4 \\
Agricultural raw materials & 0.026 & 2.232 & 10.65 & 3.29 & 3.31 \\
Food & 0.167 & 14.242 & 4.99 & 21.14 & 21.1 \\
Ores and metals & 0.108 & 9.215 & 10.63 & 13.67 & 13.65 \\
Other & 0.454 & 38.841 & 10.73 & 57.47 & 57.54 \\
Total & 0.79 & 67.5 & 10.64 & 100 & 100 \\
\hline
\end{tabular}

Source: http://data.worldbank.org/indicator/.

* calculated by the author.

Figure 1 illustrate the changes of the structure of merchandise imports during the period 1970-2014. Agricultural raw materials imports shares witnessed an obviously decline at the same period although the positive average growth rates during the period.

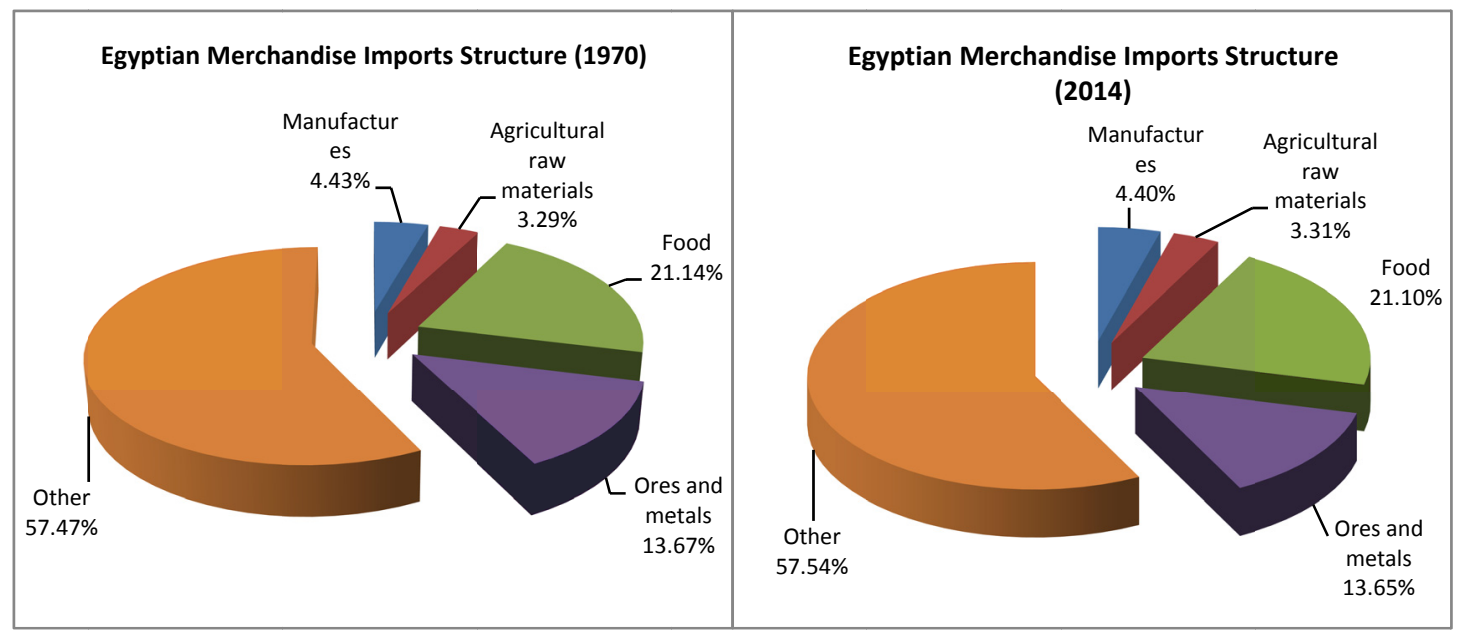

Figure 1. The structure of Egyptian merchandise imports 1970-2014

Source: Drawn by the author from Table 3.

Table 4 presents Egypt's main merchandise imports foreign suppliers in 1970 and 2014. As it can be seen from table, high-income economies have the highest share in merchandise imports in 1970 and 2014 which reached in 2014 about $64.93 \%$ of Egyptian total merchandise imports. The developing economies outside region achieved the second level with $32.8 \%$ of total merchandise imports in Egypt, after that Arab World achieved the third level with $13.65 \%$ which also has been doubled during the period 1970-2014. The relative importance of some regions in total merchandise imports has been obviously increased such as developing economies in Europe \& Central Asia, developing economies in Latin America \& the Caribbean and developing economies in East Asia \& Pacific. On the other hand, the relative importance of some regions in total merchandise imports has been decreased such as developing economies in South Asia, developing economies in Sub-Saharan Africa and developing economies in Middle East \& North Africa.

Table 4. The relative importance of Egypt's merchandise imports foreign suppliers by region (1970-2014)

\begin{tabular}{lll}
\hline \multirow{2}{*}{ From } & $\begin{array}{l}\text { Relative } \\
(\%)\end{array}$ & Importance* \\
\cline { 2 - 3 } & 1970 & 2014 \\
Arab World & 5.97 & 13.65 \\
High-income economies & 50.9 & 64.93 \\
Developing economies outside region & 20.42 & 32.8 \\
Developing economies in East Asia \& Pacific & 2.38 & 14.25 \\
\hline
\end{tabular}




\begin{tabular}{lll}
\hline $\begin{array}{l}\text { Developing economies in Europe \& Central Asia } \\
\begin{array}{l}\text { Developing economies in Latin America \& the } \\
\text { Caribbean }\end{array}\end{array}$ & 0.06 & 3.385 \\
$\begin{array}{l}\text { Developing economies in Middle East \& North } \\
\text { Africa }\end{array}$ & 3.39 & 2.24 \\
$\begin{array}{l}\text { Developing economies in South Asia } \\
\text { Developing economies in Sub-Saharan Africa }\end{array}$ & 9.88 & 3.11 \\
\hline
\end{tabular}

Source: http://data.worldbank.org/indicator/.

\section{The Model and the Methods}

Previous empirical and theoretical work suggests that imports demand is influenced by number of important factors. In the following, we advance a number of hypotheses concerning the relationship between the merchandise imports demand and the possible factors influencing it, which we will proceed to evaluate in the following empirical work. The merchandise imports demand is generally affected as follows:

$$
\mathrm{RM}=\mathrm{f} \text { (RGDP, INF, REER, RES) }
$$

Where RM is the real value of merchandise imports, RGDP is the real gross domestic product; INF is the inflation rate; REER is the real effective exchange rate and finally RES is the real international reserves.

An OLS model is estimated to explain the demand for merchandise imports in Egypt by using data from 1970 to 2014. Accordingly, For long run:

$$
\log (R M)=C_{0}+C_{1} \log (R G D P)+C_{2} \log (I N F)+C_{3} \log (R E E R)+C_{4} \log (R E S)+\xi
$$

We sourced data for the study from World Development Indicators (2014). All variables were transformed into natural logarithm to avoid the problem of heteroscedasticity and obtain elasticities.

If the variables are cointegrated, they can be represented equivalently in terms of a short run OLS framework. The most common procedure to test for cointegration is the Engle-Granger two-step estimation technique (EG). The first step in this method implies fitting the long-run relationship in levels by OLS and using the resulted residuals to test the hypothesis of cointegration by applying the PP test. If the hypothesis of cointegration is accepted, then there exists an error correction representation (Phillips and Perron, 1988). Then, the next step is to construct the error correction model, which represents the short-run dynamics.

$$
\begin{aligned}
& \Delta \log (R M)=C_{0}+C_{1} \Delta \log (R G D P)+C_{2} \Delta \log (I N F)+C_{3} \Delta \log (R E E R)+C_{4} \Delta \log (R E S) \\
& +C_{5} E C T_{t-1}+\xi
\end{aligned}
$$

Where ECT(-1) is one lag error correction term and $\Delta$ is the difference operator.

Another procedure to test for cointegration is developed by Johansen and Julesius (1992), and it is known as the maximum likelihood (ML) approach. This method estimates and tests for multiple cointegrating vectors (multivariate cointegration). It applies the analysis of the vector auto-regressive (VAR) model where all variables are treated as endogenous.

The sign and significance of the coefficient of error correction term $\mathrm{ECT}_{\mathrm{t}-1}$ describes about the existence of short run relationship. Its value and sign tells about the speed and convergence or divergence to or from the long run equilibrium. Its negative value indicates about the convergence whereas its positive value indicates about the divergence. A significant coefficient of error correction with negative sign is considered as a further proof of the existence of stable long run relationship (Banerjee et al., 1998).

\section{Empirical Results}

Phillips-Perron (PP) unit roots test is calculated for individual series to provide evidence as to whether the variables are stationary and integrated of the same order.

The results for each variable appear in Table 5. As shown in Table 5, the null hypothesis of a unit root can't be rejected for levels of all variables but the null hypothesis is rejected for the first differences of all variables. Therefore, we conclude that the series are integrated of order one. 
Table 5. PP Unit root test results

\begin{tabular}{lll}
\hline & & PP \\
\hline \multirow{2}{*}{$\log (\mathrm{M})$} & Level & -1.545343 \\
& First Diff. & $-5.534322^{\mathrm{a}}$ \\
$\log (\mathrm{RGDP})$ & Level & -0.838851 \\
& First Diff. & $-6.907689^{\mathrm{a}}$ \\
$\log (\mathrm{INF})$ & Level & -2.337139 \\
& First Diff. & $-8.336852^{\mathrm{a}}$ \\
$\log (\mathrm{REER})$ & Level & -0.520675 \\
& First Diff. & $-4.183598^{\mathrm{a}}$ \\
$\log (\mathrm{RES})$ & Level & -2.341485 \\
& First Diff. & $-4.778754^{\mathrm{a}}$ \\
\hline
\end{tabular}

Notes: Phillips and Perron (1988) unit root test with the Ho: Variables are I (1); a indicates significance at the $1 \%$ level.

Cointegration analysis refers to the process of getting equilibrium or long-run relationships among non-stationary variables. The idea is that although the variables are non-stationary, a linear combination of them may be stationary, given that all variables are integrated of the same order (Engle and Granger, 1987). The vector that links the variables in the long-run relationship is called the cointegrating vector. The estimated OLS model as it shown in Table (A-2) is:

$$
\log (M)=-2.69+1.61 \log (R G D P)+0.18 \log (I N F)-1.26 \log (R E E R)+0.12 \log (R E S)+\xi
$$

Table 6 illustrates the PP unit root test result for residual which indicates that the residual is integrated at $5 \%$ level, so the hypothesis of cointegration is accepted, then there exists an error correction representation

Table 6. PP unit root test for residual

a indicates significance at $1 \%$ level.

\begin{tabular}{ll}
\hline & Level \\
\hline Residuals & $-6.039943^{\mathrm{a}}$ \\
\hline
\end{tabular}

Table 7 and Table 8 give the results of the Likelihood Ratio tests based on the Maximum Eigenvalue and the Trace of the stochastic matrix respectively. Both these tests confirm the existence of one cointegrating vector between the variables, i.e. the existence of long-run relationship between them.

Table 7. Cointegration test based on Trace of the Stochastic Matrix

\begin{tabular}{|c|c|c|c|c|}
\hline $\begin{array}{ll}\text { Hypothesized } & \text { No. } \\
\text { of } C E(s) & \end{array}$ & Eigenvalue & Trace Statistic & 0.05 Critical Value & Prob.** \\
\hline None * & 0.576140 & 75.99147 & 69.81889 & 0.0148 \\
\hline At most $1 *$ & 0.358194 & 38.22399 & 47.85613 & 0.2923 \\
\hline At most $2 *$ & 0.244213 & 18.71133 & 29.79707 & 0.5138 \\
\hline At most $3 *$ & 0.118122 & 6.391527 & 15.49471 & 0.6492 \\
\hline At most $4 *$ & 0.019371 & 0.860681 & 3.841466 & 0.3535 \\
\hline
\end{tabular}

Trace test indicates 1 cointegrating eqn(s) at the 0.05 level

$*$ denotes rejection of the hypothesis at the 0.05 level

Table 8. Cointegration test based on Maximal Eigenvalue of the Stochastic Matrix

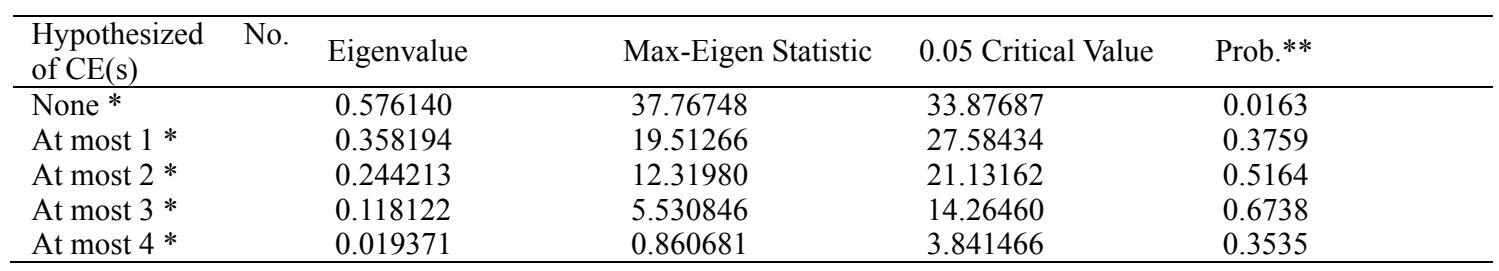

Max-eigenvalue test indicates 1 cointegrating eqn(s) at the 0.05 level

* denotes rejection of the hypothesis at the 0.05 level

Since these variables are cointegrated, they can be represented equivalently in terms of a short run OLS regression. Then, the next step is to construct the error correction model, which represents the short-run dynamics.

$$
\begin{aligned}
& \Delta \log \left(M_{t}\right)=0.018+1.25 * \Delta \log \left(R_{R D P_{t}}\right)+0.056 * \Delta \log \left(\operatorname{INF}_{t}\right)-1.21 * \Delta \log \left(\operatorname{REER}_{t}\right) \\
& -0.11 * \Delta \log \left(\operatorname{RES}_{t}\right)-0.85 * E C T_{t-1}+\xi_{t}
\end{aligned}
$$

The robustness of the model has been definite by several diagnostic tests as shown in Tables (A-4), (A-5), (A-6) and (A-7) in the appendix, such as Breusch- Godfrey serial correlation LM test, Breusch-Pagan-Godfrey Heteroskedasticity 
test, ARCH test and Jacque-Bera normality test. All the tests disclosed that the model has the aspiration econometric properties, it has a correct functional form and the model's residuals are serially uncorrelated, normally distributed and homoskedastic. Therefore, the outcomes reported are serially uncorrelated, normally distributed and homoskedastic. Hence, the results reported are valid for reliable interpretation.

The stability of the long-run coefficient is tested by the short-run dynamics. Once the ECM model given by equation (5) has been estimated, the cumulative sum of recursive residuals (CUSUM) and the CUSUM of square (CUSUMSQ) tests are applied to assess the parameter stability (Pesaran \& Pesaran (1997)). Figure 2 plot the results for CUSUM and CUSUMSQ tests. The results indicate the absence of any instability of the coefficients because the plot of the CUSUM and CUSUMSQ statistic fall inside the critical bands of the 5\% confidence interval of parameter stability.

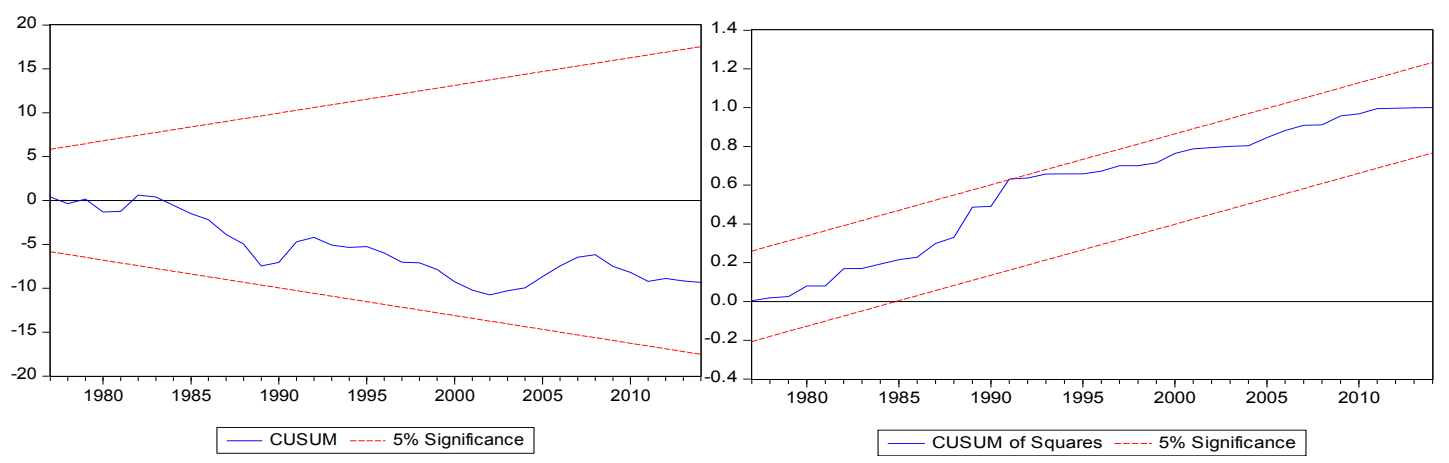

Figure 2. Parameters Stability Tests of Short-run Model

The error correction is correctly negatively signed and highly significant and has a high magnitude (-0.85) suggesting a speed adjustment process, which means that, if merchandise import demand is 1 percent out of equilibrium, a 85 percent adjustment towards equilibrium will take place within the first year.

Table 9 summarizes the critical parameters of merchandise import demand determinants for Egypt for the period 1970-2014 by using ordinary least squares (OLS) and error correction model approach. The empirical results confirm that, in both long run and short run, there is positive and significant relationship between the demand for merchandise imports and real gross domestic product, but there is a negative and significant relationship between the demand of merchandise imports and real effective exchange rate. On the other hand, in the long run, there are positive and significant relationships between the demand for merchandise imports and both of inflation and international reserves but insignificant relationships in the short run.

Table 9. OLS estimates for the long run and short run (1970-2014)

\begin{tabular}{|c|c|c|}
\hline \multirow{2}{*}{ Variable } & \multicolumn{2}{|l|}{ Coefficient } \\
\hline & Long Run & Short Run \\
\hline $\mathrm{C}$ & -2.69 & $0.018^{\mathrm{b}}$ \\
\hline LOG(RGDP) & $1.61^{\mathrm{a}}$ & $1.25^{\mathrm{b}}$ \\
\hline LOG(INF) & $0.18^{\mathrm{a}}$ & 0.057 \\
\hline LOG(REER ) & $-1.26^{\mathrm{a}}$ & $-1.21^{\mathrm{a}}$ \\
\hline LOG(RES ) & $0.12^{\mathrm{b}}$ & -0.11 \\
\hline \multirow[t]{3}{*}{$\mathrm{ECT}(-1)$} & - & $-0.85^{\mathrm{a}}$ \\
\hline & $\mathrm{R}^{2}=93.6$ & $\mathrm{R}^{2}=69.2$ \\
\hline & Durbin-Watson: 1.85 & Durbin-Watson: 1.40 \\
\hline
\end{tabular}

Source: Table (A-2) and table (A-3) in Appendix.

- $a$ and $b$ denotes significance level at $1 \%$ and $5 \%$ respectively.

\section{Concluding Remarks and Policy Implications}

Merchandise imports in Egypt is growing steadily and very rapidly, at an average growth rate of 10.64 percent/year during 1970-2014. So, this study is very important to know the merchandise imports determinants in Egyptian economy. This study empirically estimated the critical parameters of merchandise import demand determinants for Egypt by using Ordinary Least Squares (OLS) approach and Error Correction model during the period (1970-2014).

The empirical results confirmed that, in both long run and short run, there is positive and significant relationship between the demand for merchandise imports and real gross domestic product, but there is a negative and significant relationship between the demand of merchandise imports and real effective exchange rate. On the other hand, in the long run, there are positive and significant relationships between the demand for merchandise imports and both of inflation and international reserves but insignificant relationships in the short run. 
These findings obviously have implications for the trade balance. The merchandise imports volume would rise significantly if real income were to increase, and that too at a rate higher than the rate of growth of real income, thus causing the trade balance to deteriorate. To prevent this, exports must grow in tandem with imports. With a stagnant export growth rate and a very high import growth rate, the trade balance will keep worsening. Policy propositions to reduce imports and improve the trade balance are, therefore, common. The real concern, however, is to improve the trade balance without having to reduce imports. If recovery is to come from anywhere, it must come from the export side, given the nature of Egyptian's imports and the fact that it is not self-sufficient in producing what it currently should import.

\section{References}

Al-Dakhil, K., \& Al-Yousef, N. (2002). Aggregate import demand function for Saudi Arabia: An error correction approach. Journal of Economic \& Administrative Sciences, 18, 83-100.

Alias, H. M., \& Tang. T. C. (2000). Aggregate imports and expenditure components in Malaysia: A cointegration and error correction analysis. ASEAN Economic Bulletin, 17, 257-269. https://doi.org/10.1355/AE17-3B

Aljebrin M. A., \& Ibrahim M. A. (2012). The Determinants of the Demand for Imports in GCC Countries. International Journal of Economics and Finance, 4(3), 126-138. https://doi.org/10.5539/ijef.v4n3p126

Arize, A. C., \& Malindretos, J. (2012). Foreign exchange reserve in Asia and its impact on import demand, International Journal of Economics and Finance, 4(3), 21-32. https://doi.org/10.5539/ijef.v4n3p21

Bahmani-Oskooee, M. (1998). Cointegration approach to estimate the long-run trade elasticities in LDCs, International Economic Journal, 12(3), 89-96. https://doi.org/10.1080/10168739800080024

Breusch, T. S., \& Pagan, A. R. (1979). A Simple Test for Heteroscedasticity and Random Coefficient Variation. Econometrica, 47 (5), 1287-1294. https://doi.org/10.2307/1911963

Carone, G. (1996). Modeling the U. S. demand for imports through cointegration and error correction. Journal of Policy Modeling, 18, 1-48. https://doi.org/10.1016/0161-8938(95)00058-5

Doroodian et al (1994). An examination of the traditional import demand function for Saudi Arabia. Applied Economics, 26, 909-915. https://doi.org/10.1080/00036849400000052

Dutta, D., \& Ahmed. N. (2006). An aggregate import demand function for India: A cointegration analysis. School of Economics and Political Science, University of Sydney, Australia. Retrieved from https://digitalcollections.anu.edu.au/handle/1885/40314

Engle, R. F., \& C.W.J. Granger (1987). Cointegration and Error Correction: Representation, Estimation and Testing. Econometrica, 55(2), 251-276. https://doi.org/10.2307/1913236

Erlat, G., \& Erlat, H. (1991). An empirical study of Turkish export and import function. CBRT and METU.

Hicks A. (1994). Introduction to pooling. In T. Janoski and A. Hicks (edited by), The Comparative Political Economy of the Welfare State (pp. 54-92), Cambridge University Press, UK. https://doi.org/10.1017/cbo9781139174053.007

Ibrahim, M. A. (2015). Merchandise Import Demand Function in Saudi Arabia”, Applied Economics and Finance, 2(1), 55-65. Retrieved from: http://redfame.com/journal/index.php/aef/article/view/626.

Jarque, C. M., \& Bera, A. K. (1981). Efficient tests for normality, homoscedasticity and serial independence of regression residuals: Monte Carlo evidence. Economics Letters, 7(4), 313-318. https://doi.org/10.1016/0165-1765(81)90035-5

Johansen, S., \& Juselius, K. (1992). Testing Structural Hypothesis in a Multivariate Cointegration Analysis of the PPP and the UIP for UK. Journal of Econometrics. 53, 211-244. https://doi.org/10.1016/0304-4076(92)90086-7

Kotan, Z., \& Saygili, M. (1999). Estimating an import demand function For Turkey. Discussion paper, no: 9909, The Central Bank of the Republic of Turkey, Research Department,Turkey. https://doi.org/10.1016/S0304-4076(01)00098-7

Metwally, M. (2004). Determinants of aggregate imports in the GCC Countries. Applied Econometrics and International Development (AEID), 4-3, 59-76. https://doi.org/10.1355/AE17-3B

Mohammed, H. A., \& Tang, T. C. (2000). Aggregate imports and expenditure components in Malaysia: A cointegration and error correction analysis. ASEAN Economic Bulletin, 17, 257-269. Retrieved from

Pesaran, M. H., \& Pesaran, B. (1997). Working with Microfit 4.0: Interactive Econometric Analysis. Oxford University Press, Oxford.

Phillips, P. C., \& Perron, P. (1988). Testing for a unit root in time series regression. Biometrika, 75, 335-346. 
https://doi.org/10.1093/biomet/75.2.335

Rashid, A., \& Razzaq, T. (2010). Estimating import-demand function in ARDL framework: The case of Pakistan (MPRA Paper No. 23702). Retrieved from:

http://mpra.ub.uni-muenchen.de/23702/1/ESTIMATION_OF_IMPORT_DEMAND_ FUNCTION_FOR_PAKISTAN.pdf

Sinha, D. (2001). A Note on Trade Elasticities in Asian Countries. The International Trade Journal, XV, 221-237. https://doi.org/10.1080/088539001316901042

Stirbock, C. (2006). How strong is the impact of exports and other demand components on German import demand? Evidence from euro-area and non-euro-area imports. Discussion paper. Economic studies, 1, Deutsche Bundesbank Frankfurt, Germany. Retrieved from http://econstor.eu/bitstream/10419/19668/1/200639dkp.pdf.

World Bank, World Bank Developmevt Indicator, http://data.worldbank.org/indicator/ 


\section{Appendix}

Appendix (A)

Table (A-1). Economic Data (1970-2014)

\begin{tabular}{|c|c|c|c|c|c|}
\hline Period & $\begin{array}{l}\text { Real } \\
\text { Merchandise } \\
\text { Imports } \\
(2010=100) \\
\text { (Billion } \\
\text { Dollar) } \\
\end{array}$ & $\begin{array}{l}\text { Real Gross } \\
\text { Domestic } \\
\text { Product } \\
(2010=100) \\
\text { (Billion } \\
\text { Pound) } \\
\end{array}$ & $\begin{array}{l}\text { Real } \\
\text { International } \\
\text { Reserves } \\
(2010=100) \\
\text { (Billion } \\
\text { Dollar) } \\
\end{array}$ & $\begin{array}{l}\text { Inflation } \\
(\%)\end{array}$ & $\begin{array}{l}\text { Real } \\
\text { Effective } \\
\text { Exchange } \\
\text { Rate }\end{array}$ \\
\hline 1970 & 47.96 & 186.47 & 10.06 & 3.76 & 0.43 \\
\hline 1971 & 54.37 & 191.59 & 9.65 & 3.14 & 0.43 \\
\hline 1972 & 52.04 & 196.26 & 12.12 & 2.10 & 0.43 \\
\hline 1973 & 50.41 & 209.65 & 29.33 & 5.11 & 0.40 \\
\hline 1974 & 117.71 & 217.21 & 35.31 & 10.02 & 0.39 \\
\hline 1975 & 179.56 & 238.19 & 24.42 & 9.67 & 0.39 \\
\hline 1976 & 157.54 & 278.35 & 23.47 & 10.32 & 0.39 \\
\hline 1977 & 176.75 & 306.26 & 30.53 & 12.73 & 0.39 \\
\hline 1978 & 222.28 & 323.67 & 34.71 & 11.08 & 0.39 \\
\hline 1979 & 115.37 & 381.99 & 53.97 & 9.90 & 0.70 \\
\hline 1870 & 120.94 & 410.53 & 61.71 & 20.82 & 0.70 \\
\hline 1981 & 199.39 & 390.70 & 37.96 & 10.32 & 0.70 \\
\hline 1982 & 178.34 & 408.26 & 35.55 & 14.82 & 0.70 \\
\hline 1983 & 173.90 & 409.06 & 28.75 & 16.08 & 0.70 \\
\hline 1984 & 155.68 & 412.19 & 21.49 & 17.04 & 0.70 \\
\hline 1985 & 143.23 & 427.37 & 20.48 & 12.11 & 0.70 \\
\hline 1986 & 119.78 & 399.43 & 18.53 & 23.86 & 0.70 \\
\hline 1987 & 141.16 & 448.65 & 22.24 & 19.69 & 0.70 \\
\hline 1988 & 172.27 & 456.33 & 16.72 & 17.66 & 0.70 \\
\hline 1989 & 92.15 & 468.26 & 15.22 & 21.26 & 0.87 \\
\hline 1990 & 64.82 & 502.10 & 18.91 & 16.76 & 1.55 \\
\hline 1991 & 35.12 & 485.18 & 26.98 & 19.75 & 3.14 \\
\hline 1992 & 31.95 & 533.86 & 44.60 & 13.64 & 3.32 \\
\hline 1993 & 28.12 & 531.41 & 47.44 & 12.09 & 3.35 \\
\hline 1994 & 32.35 & 554.03 & 45.63 & 8.15 & 3.39 \\
\hline 1995 & 32.17 & 558.00 & 46.83 & 15.74 & 3.39 \\
\hline 1996 & 33.27 & 585.40 & 46.69 & 7.19 & 3.39 \\
\hline 1997 & 32.22 & 648.54 & 47.25 & 4.63 & 3.39 \\
\hline 1998 & 37.96 & 674.85 & 44.20 & 3.87 & 3.39 \\
\hline 1999 & 36.50 & 700.70 & 34.60 & 3.08 & 3.40 \\
\hline 2000 & 32.34 & 754.49 & 30.58 & 2.68 & 3.47 \\
\hline 2001 & 29.02 & 778.09 & 29.50 & 2.27 & 3.97 \\
\hline 2002 & 26.96 & 800.01 & 29.72 & 2.74 & 4.50 \\
\hline 2003 & 26.16 & 843.49 & 29.50 & 4.51 & 5.85 \\
\hline 2004 & 28.96 & 881.16 & 27.85 & 11.27 & 6.20 \\
\hline 2005 & 38.87 & 932.35 & 37.84 & 4.87 & 5.78 \\
\hline 2006 & 43.91 & 993.53 & 41.83 & 7.64 & 5.73 \\
\hline 2007 & 54.59 & 1095.84 & 47.40 & 9.32 & 5.64 \\
\hline 2008 & 60.16 & 1113.59 & 42.69 & 18.32 & 5.43 \\
\hline 2009 & 50.01 & 1159.61 & 38.83 & 11.76 & 5.54 \\
\hline 2010 & 52.92 & 1206.60 & 37.03 & 11.27 & 5.62 \\
\hline 2011 & 53.52 & 1245.84 & 16.93 & 10.05 & 5.93 \\
\hline 2012 & 58.70 & 1336.44 & 13.29 & 7.12 & 6.06 \\
\hline 2013 & 45.19 & 1359.20 & 12.82 & 9.42 & 6.87 \\
\hline 2014 & 47.50 & 1405.95 & 10.51 & 10.15 & 7.08 \\
\hline
\end{tabular}

Source: World Bank, World Bank Development Indicator. 
Table (A-2). Ordinary Least Squares Regression Results (Long Run Relationship)

\begin{tabular}{|c|c|c|c|c|}
\hline $\begin{array}{l}\text { Dependent Variable: } \\
\text { Method: Least Squat } \\
\text { Date: } 05 / 06 / 16 \\
\text { Sample: } 19702014 \\
\text { Included observation }\end{array}$ & $\begin{array}{l}\text { (M) } \\
17\end{array}$ & & & \\
\hline Variable & Coefficient & Std. Error & t-Statistic & Prob. \\
\hline LOG(RGDP) & 1.612548 & 0.144082 & 11.19189 & 0.0000 \\
\hline LOG(INF) & 0.176343 & 0.047752 & 3.692856 & 0.0007 \\
\hline LOG(REER) & -1.263885 & 0.078837 & -16.03159 & 0.0000 \\
\hline LOG(RES) & 0.120520 & 0.059563 & 2.023406 & 0.0497 \\
\hline $\mathrm{C}$ & -2.687122 & 0.191836 & -14.00740 & 0.0000 \\
\hline R-squared & 0.936240 & Mean dependent var & -0.437616 & \\
\hline Adjusted R-squared & 0.929864 & S.D. dependent var & 0.685539 & \\
\hline S.E. of regression & 0.181553 & Akaike info criterion & -0.470102 & \\
\hline Sum squared resid & 1.318456 & Schwarz criterion & -0.269362 & \\
\hline Log likelihood & 15.57730 & Hannan-Quinn criter. & -0.395268 & \\
\hline F-statistic & 146.8381 & Durbin-Watson stat & 1.853503 & \\
\hline Prob(F-statistic) & 0.000000 & & & \\
\hline
\end{tabular}

Table (A-3). Ordinary Least Squares Regression Results (Short Run Relationship)

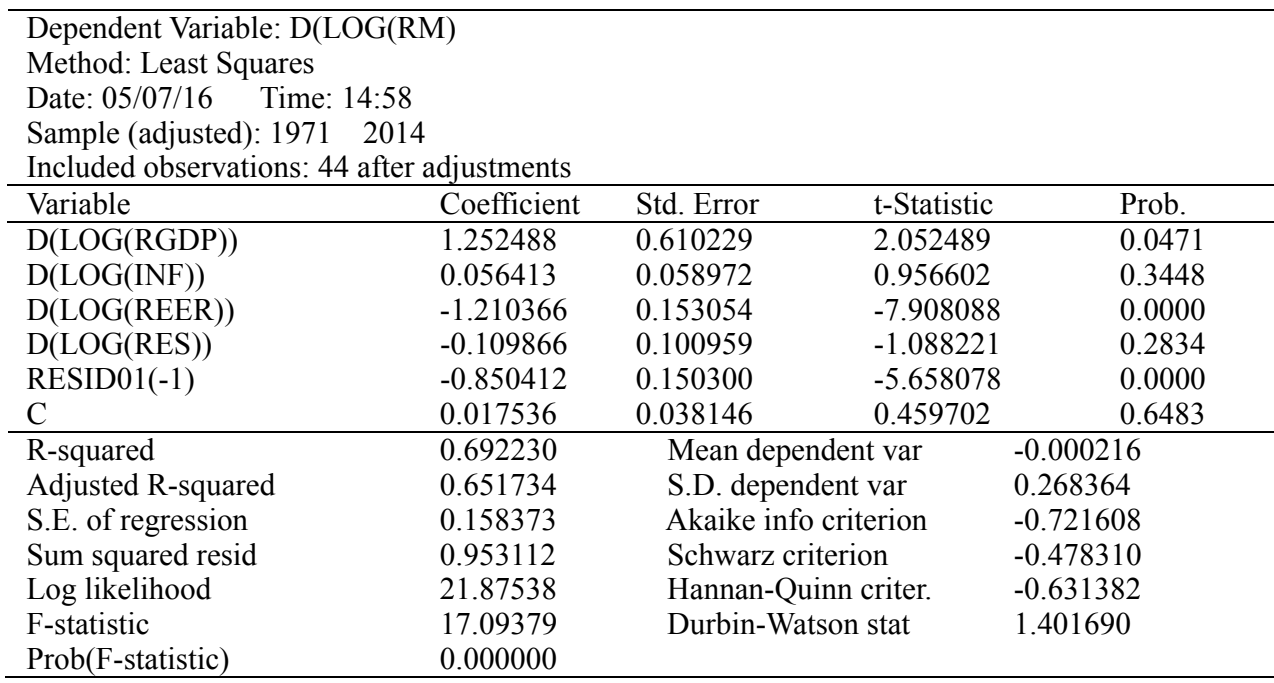

Table (A-4). Breusch- Godfrey serial correlation LM test for Short-run Model

\begin{tabular}{llll}
\hline F-statistic & 10.05214 & Prob. F(2,36) & 0.0003 \\
Obs*R-squared & 15.76686 & Prob. Chi-Square(2) & 0.0004 \\
\hline
\end{tabular}

Table (A-5). Residuals Breusch-Pagan-Godfrey Heteroskedasticity Test of Short-run Model

\begin{tabular}{lrlr}
\hline F-statistic $\quad 0.472387$ & Prob. F(5,38) & 0.7944 \\
Obs*R-squared2.574830 & Prob. Chi-Square(5) & 0.7652
\end{tabular}

Table (A-6). Residuals ARCH Heteroskedasticity Test of Short-run Model

\begin{tabular}{llll}
\hline F-statistic & 0.415163 & Prob. F(1,41) & 0.5229 \\
Obs*R-square & & & \\
d & 0.431050 & Prob. Chi-Square(1) & 0.5115
\end{tabular}

Table (A-7). Residuals Normality Test of Short-run Model

$\begin{array}{ll}\text { Jarque-Bera } & \text { Prob. } \\ 0.637820 & 0.726941\end{array}$

\section{Copyrights}

Copyright for this article is retained by the author(s), with first publication rights granted to the journal.

This is an open-access article distributed under the terms and conditions of the Creative Commons Attribution license which permits unrestricted use, distribution, and reproduction in any medium, provided the original work is properly cited. 